\title{
Kinetic and Spectrophotometric Determination of Trace Zinc(II) in the Presence of a Large Amount of Lead(II) Using Ligand- Substitution Reactions of Their Metalloporphyrins with EDTA
}

\author{
Masaaki Tabata and Naoko KaJiHaRA \\ Department of Chemistry, Faculty of Science and Engineering, Saga University, Saga 840, Japan
}

\begin{abstract}
The formation constant of lead(II) complex of 5,10,15,20-tetrakis(4-sulfonatophenyl)porphine $\left(\mathrm{H}_{2}\right.$ TPPS $\left._{4}\right)$ (log K) defined as $\mathrm{Pb}^{2+}+\mathrm{H}_{2} \mathrm{TPPS}_{4} \rightleftharpoons \mathrm{Pb}(11)\left(\mathrm{TPPS}_{4}\right)+2 \mathrm{H}^{+}$was found to be $-9.97 \pm 0.02$, which is approximately $10^{9}$ times as small as that of $\mathrm{Zn}(\mathrm{II})\left(\mathrm{TPPS}_{4}\right)$. In addition, Pb(II)(TPPS 4 ) was rapidly replaced with EDTA at a half-life time of $200 \mathrm{~ms}$. On the other hand, $\mathrm{Zn}($ (II)(TPPS 4 is stable and not replaced with EDTA even after $2 \mathrm{~h}$. The large difference in the equilibrium and kinetic behavior between $\mathrm{Zn}(\mathrm{II})$ - and $\mathrm{Pb}(\mathrm{II})\left(\mathrm{TPPS}_{4}\right)$ allows the determination of $\mathrm{zinc}(\mathrm{II})$ at as low as $10^{-7} \mathrm{~mol} \mathrm{dm}^{-3}$ concentration level in the presence of $10^{-2} \mathrm{~mol} \mathrm{dm}^{-3}$ lead(II). The molar absorptivity of $\mathrm{Zn}(I)\left(\mathrm{TPPS}_{4}\right)$ is $4.66 \times 10^{5} \mathrm{~mol}^{-1} \mathrm{dm}^{3} \mathrm{~cm}^{-1}$. The method was applied to the determination of zinc(II) in lead chemicals (lead(II) nitrate, lead(II) acetate and lead metal) and in tap and waste waters by measurement of the absorbance at $421 \mathrm{~nm}$. The optimum conditions of the ligand-buffer solution containing aminopolycarboxylates and lead(II) are described to remove the interference of copper(II), cobalt(II) and manganese(II).
\end{abstract}

Keywords Zinc(II) determination, lead(II) chemicals, water, spectrophotometry, porphyrin

Most of colorimetric reagents for the determination of metals form stabler complexes with lead(II) than with zinc(II). 1,2 Therefore, it is difficult to determine zinc(II) spectrophotometrically in the presence of a large amount of lead(II). However, we found that the formation constant of zinc(II) with tetrakis(4-sulfonatophenyl)porphine $\left(\mathrm{H}_{2} \mathrm{TPPS}_{4}\right)$ is larger by about $10^{9}$ times than that of lead(II). In addition, $\mathrm{Zn}(\mathrm{II})\left(\mathrm{TPPS}_{4}\right)$ is stable and is not replaced with ethylenediaminetetraacetic acid (EDTA) even after $2 \mathrm{~h}$, while $\mathrm{Pb}(\mathrm{II})\left(\mathrm{TPPS}_{4}\right)$ is completely replaced with EDTA within $2 \mathrm{~s}$. The large differences in the equilibrium and kinetic behavior between $\mathrm{Zn}(\mathrm{II})$ - and $\mathrm{Pb}(\mathrm{II})\left(\mathrm{TPPS}_{4}\right)$ were applied to the determination of zinc(II) in the presence of a large amount of lead(II). The high molar absorptivity of $\mathrm{Zn}(\mathrm{II})\left(\mathrm{TPPS}_{4}\right)\left(4.66 \times 10^{5} \mathrm{~mol}^{-1} \mathrm{dm}^{3} \mathrm{~cm}^{-1}\right)$ allows the determination of zinc(II) at as low as $10^{-7} \mathrm{~mol} \mathrm{dm}^{-3}$ concentration level in the presence of $10^{-2} \mathrm{~mol} \mathrm{dm}^{-3}$ lead(II). Zinc(II) complex with tetrakis(1-methylpyridinium-4yl)porphine $\left(\mathrm{H}_{2} \mathrm{TMPyP}\right)$ is also about $10^{8}$ to $10^{9}$ times as stable as lead(II). ${ }^{3,4}$

The large equilibrium and kinetic differences between lead(II) and zinc(II) can be ascribed to the ionic radii difference $\left(132 \mathrm{pm}\right.$ for $\mathrm{Pb}^{2+} ; 89 \mathrm{pm}$ for $\left.\mathrm{Zn}^{2+}\right)$. Large metal ions such as lead(II), mercury(II) and cadmium(II) can not incorporate well into porphyrin core and just sit on the porphyrin plane. ${ }^{5-8}$ Barkiga et al. called lead(II) porphyrin a "roof complex" after an X-ray analysis of tetrakispropylporphinatolead(II). ${ }^{9} \quad$ The roof metalloporphyrin therefore dissociates easily to form free porphyrin in acid or is replaced with EDTA. ${ }^{3,10-12}$ On the other hand, zinc(II) incorporates well into porphyrin core ${ }^{13,14}$ and is so stable that $\mathrm{Zn}\left(\mathrm{TPPS}_{4}\right)$ is not replaced with EDTA. Noticing a difference of $10^{12}$ times in the acid-dissociation rate of zinc(II)- and cadmium(II)(TPPS 4 ), we have proposed a kinetic method for the determination of zinc in a large excess of cadmium. ${ }^{10}$ After that, Ishii and Tsuchiai have reported a spectrophotometric and analogue derivative spectrophotometric determination of trace zinc in the presence of a high concentration of cadmium using ligand-substitution reaction with EDTA; but the extent of the different reactivity of zinc and cadmium has not been clear in both equilibrium and kinetics. ${ }^{12}$ In the present paper, we clarify both the kinetic difference of $4 \times 10^{11}$ times and the thermodynamic difference of $10^{9}$ times between zinc(II)- and lead(II)$\left(\mathrm{TPPS}_{4}\right)$ in the ligand-substitution reaction of the metalloporphyrins with EDTA, and propose a kinetic spectrophotometric determination of zinc in a large excess of lead using the ligand substitution reaction of the metalloporphyrins with EDTA.

The reaction for the present study is

$$
\mathrm{M}\left(\mathrm{TPPS}_{4}\right)+\mathrm{EDTA} \rightleftharpoons \mathrm{M}\left(\mathrm{EDTA}^{2-}+\mathrm{H}_{2} \mathrm{TPPS}_{4}\right.
$$


where $\mathbf{M}$ denotes zinc(II) or lead(II). The present method was applied to the determination of zinc(II) in lead chemicals and in tap and waste waters. The interference from copper(II) and cobalt(II) was removed by a ligand-buffer solution containing aminopolycarboxylate and lead(II).

\section{Experimental}

\section{Reagents}

$5,10,15,20$-Tetrakis(4-sulfonatophenyl)porphine $\left(\mathrm{H}_{2} \mathrm{TPPS}_{4}\right)$ was synthesized and its sodium salt was purified by a published method. ${ }^{6}$ The purity was checked by thin layer chromatography and nuclear magnetic resonance spectroscopy. Solutions of zinc(II) and lead(II) were prepared from their nitrates, and the concentrations of zinc(II) and lead(II) in the stock solutions were determined by EDTA titration. EDTA, 3-carboxymethyl-6-(2-hydroxyethyl)-3,6-diaza-heptanedioic acid (HEDTA) and 3,12-bis(carboxymethyl)-6,9dioxa-3,12-diaza-tetradecanedioic acid (EGTA) were purchased from DOJINDO Laboratories (Kumamoto, Japan). All other reagents were analytical reagent grade.

\section{Procedure}

A sample solution $\left(25 \mathrm{~cm}^{3}\right)$ containing zinc(II) $\left(10^{-7}-\right.$ $\left.2 \times 10^{-6} \mathrm{~mol} \mathrm{dm}^{-3}\right)$, lead(II) $\left(2 \times 10^{-3}-2 \times 10^{-2} \mathrm{~mol} \mathrm{dm}^{-3}\right)$ is taken in a brown $50 \mathrm{~cm}^{3}$ volumetric flask, and following solutions were added in the order as described: $5 \mathrm{~cm}^{3}$ of acetate buffer (pH 6.0;5 $510^{-1} \mathrm{~mol} \mathrm{dm}^{-3}$ ), $2.5 \mathrm{~cm}^{3}$ of imidazole $\left(1.0 \mathrm{~mol} \mathrm{dm}^{-3} ; \mathrm{pH}\right), 1 \mathrm{~cm}^{3}$ of $\mathrm{H}_{2} \mathrm{TPPS}_{4}$ $\left(1.0 \times 10^{-4} \mathrm{~mol} \mathrm{~d} \mathrm{~m}^{-3}\right)$. The solution was allowed to stand for $30 \mathrm{~min}$ to complete the formation of $\mathrm{Zn}(\mathrm{II})\left(\mathrm{TPPS}_{4}\right)$. A $5 \mathrm{~cm}^{3}$ portion of EDTA $\left(0.1 \mathrm{~mol} \mathrm{dm}^{-3}\right)$ was added to the solution to replace $\mathrm{Pb}(\mathrm{II})\left(\mathrm{TPPS}_{4}\right)$ with EDTA and the solution was diluted to the mark $\left(50 \mathrm{~cm}^{3}\right)$. The absorbance was measured at $421 \mathrm{~nm}\left(\lambda_{\max }\right.$ of $\mathrm{Zn}(\mathrm{II})-$ $\left(\mathrm{TPPS}_{4}\right)$ ).

The formation constant of lead(II)(TPPS 4 ) was determined spectrophotometrically at pH $6.0\left(N, N^{\prime}-\right.$ bis(2-sulfonatoethyl)piperazine: PIPES buffer $\left(10^{-2} \mathrm{~mol}\right.$ $\left.\mathrm{dm}^{-3}\right)$ ), at an ionic strength of $0.1 \mathrm{~mol} \mathrm{dm}^{-3}\left(\mathrm{NaNO}_{3}\right)$ and $25^{\circ} \mathrm{C}$. The absorption spectra were recorded by a Hitachi 323 UV-VIS spectrophotometer in a $1 \mathrm{~cm}$ cell with a thermostated water jacket. The $\mathrm{pH}$ values were determined by a Toa digital pH-meter HM-15A with a reference electrode (Metrohm EA 404) and a glass electrode (Metrohm EA 109). A $1.000 \times 10^{-2} \mathrm{~mol} \mathrm{dm}^{-3}$ nitric acid solution containing $0.09 \mathrm{~mol} \mathrm{dm}^{-3}$ sodium nitrate was employed as a standard of hydrogen ion concentration $\left(-\log \left[\mathrm{H}^{+}\right]=2.000\right)$.

\section{Results and Discussion}

Formation of $\mathrm{Pb}(\mathrm{II})\left(\mathrm{TPPS}_{4}\right)$

The absorption spectrum of $\mathrm{H}_{2} \mathrm{TPPS}_{4}$ changed considerably in the presence of lead(II): the absorbance at $413 \mathrm{~nm}$ decreased and that at $465 \mathrm{~nm}$ (absorption maximum of $\mathrm{Pb}(\mathrm{II})\left(\mathrm{TPPS}_{4}\right)$ increased. Under the present experimental conditions ( $\mathrm{pH} \mathrm{6.0)}$, porphyrin is in its free base form and hydrolysis of lead(II) can be negligible. The equilibrium for the formation of $\mathrm{Pb}(\mathrm{II})\left(\mathrm{TPPS}_{4}\right.$ ) is thus written by Eq. (2) (charges on porphyrin and metalloporphyrins are omitted throughout) with the equilibrium constant defined by Eq. (3)

$$
\begin{aligned}
& \mathrm{Pb}^{2+}+\mathrm{H}_{2} \mathrm{TPPS}_{4} \rightleftharpoons \mathrm{Pb}(\mathrm{II})\left(\mathrm{TPPS}_{4}\right)+2 \mathrm{H}^{+} \\
& K=\left[\mathrm{Pb}(\mathrm{II})\left(\mathrm{TPPS}_{4}\right)\right]\left[\mathrm{H}^{+}\right]^{2}\left[\mathrm{~Pb}^{2+}\right]^{-1}\left[\mathrm{H}_{2} \mathrm{TPPS}_{4}\right]^{-1} .
\end{aligned}
$$

Absorption spectra of solutions containing various concentrations of lead(II) $\left(4 \times 10^{-4}-5 \times 10^{-3} \mathrm{~mol} \mathrm{dm}^{-3}\right)$ and $\mathrm{H}_{2}$ TPPS $_{4}\left(2.0 \times 10^{-6} \mathrm{~mol} \mathrm{dm}^{-3}\right)$ show a clear isosbestic point at $428 \mathrm{~nm}$. The formation constant was determined from the change in absorbances: $\log K=$ $-9.97 \pm 0.02$. The value is $10^{9}$ times smaller than the corresponding value for $\mathrm{zinc}(\mathrm{II})(-0.43 \pm 0.03) .^{7}$

\section{Ligand-substitution reaction of $P b(I I)-$ and $\mathrm{Zn}(I I)\left(T P P S_{4}\right)$ with EDTA}

The very small formation constant of $\mathrm{Pb}(\mathrm{II})\left(\mathrm{TPPS}_{4}\right)$ compared with $\mathrm{Zn}(\mathrm{II})\left(\mathrm{TPPS}_{4}\right)$ indicates that lead(II) does not incorporate well into a porphyrin core and just sits on the porphyrin plane, as shown by an X-ray study of lead(II) porphyrin. 9 The results also imply the rapid replacement of $\mathrm{Pb}(\mathrm{II})\left(\mathrm{TPPS}_{4}\right)$ with EDTA. Figure 1 shows the kinetic runs for the ligand-substitution reaction of $\mathrm{Pb}(\mathrm{II})-$ and $\mathrm{Zn}(\mathrm{II})\left(\mathrm{TPPS}_{4}\right)$ with EDTA $\left(10^{-2} \mathrm{~mol} \mathrm{dm}^{-3}\right)$ at $\mathrm{pH}$ 6.0. $\mathrm{Pb}(\mathrm{II})\left(\mathrm{TPPS}_{4}\right)$ is replaced with EDTA at a half-life time of $200 \mathrm{~ms}$, but $\mathrm{Zn}$ (II)$\left(\mathrm{TPPS}_{4}\right)$ is not replaced even after $2 \mathrm{~h}$. The conditional formation constants defined as $K^{\prime}=\left[\mathrm{M}\left(\mathrm{TPPS}_{4}\right)\right]\left[\mathrm{M}^{2+}\right]^{-1} \times$

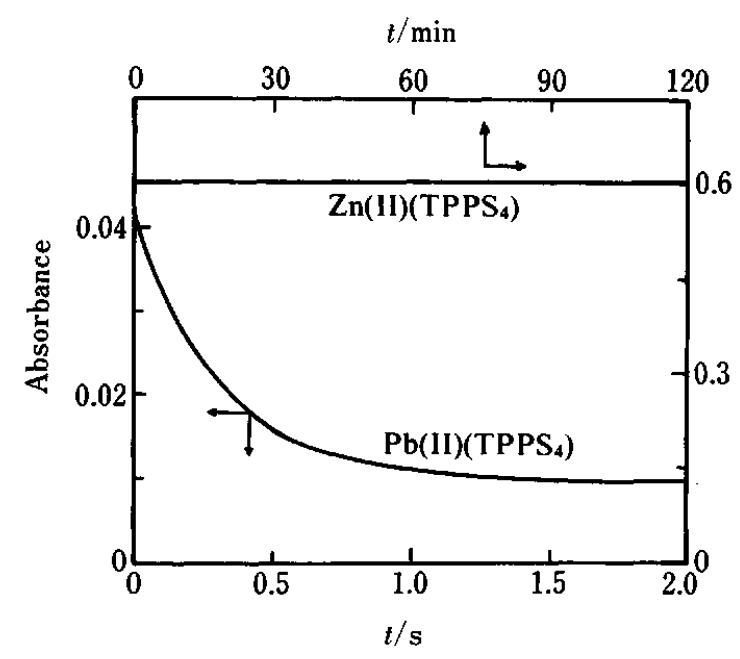

Fig. 1 Ligand-substitution reaction of $\mathrm{Zn}(\mathrm{II})\left(\mathrm{TPPS}_{4}\right)$ and $\mathrm{Pb}(\mathrm{II})\left(\mathrm{TPPS}_{4}\right)$ with EDTA $\left(C_{\text {EDTA }}=10^{-2} \mathrm{~mol} \mathrm{dm}^{-3}\right)$ at $25^{\circ} \mathrm{C}$ and $\mathrm{pH} 6.0$. 
$\left[\mathrm{H}_{2} \mathrm{TPPS}_{4}\right]^{-1}=K\left[\mathrm{H}^{+}\right]^{-2}\left(\mathrm{M}=\mathrm{Pb}^{2+}\right.$ and $\left.\mathrm{Zn}^{2+}\right)$ are $10^{2.03}$ and $10^{11.5}$ at $\mathrm{pH} 6.0$ for lead(II)- and zinc(II)(TPPS 4 ), respectively. The conditional formation constants of the $\mathrm{Pb}(\mathrm{II})$ - and $\mathrm{Zn}(\mathrm{II})\left(\right.$ EDTA) complexes are $10^{13.55}$ and $10^{11.91}$ at $\mathrm{pH} 6.0 .^{2}$ Comparison of the conditional formation constants of $\mathrm{Zn}(\mathrm{II})\left(\mathrm{TPPS}_{4}\right)$ with that of $\mathrm{Zn}$ (II)(EDTA) predicts that $\mathrm{Zn}(\mathrm{II})\left(\mathrm{TPPS}_{4}\right)$ would be replaced thermodynamically with EDTA in a large excess of EDTA at pH 6.0 ( $C_{\mathrm{H} 2 \mathrm{TPPS}}=2.0 \times 10^{-6} \mathrm{~mol}$ $\mathrm{dm}^{-3}$ and $C_{\text {EDTA }}=10^{-2} \mathrm{~mol} \mathrm{dm}^{-3}$ ). The rate of the ligandsubstitution reaction of $\mathrm{Pb}(\mathrm{II})\left(\mathrm{TPPS}_{4}\right)$ depends on both EDTA and hydrogen ion concentrations. In contrast, that of $\mathrm{Zn}(\mathrm{II})\left(\mathrm{TPPS}_{4}\right)$ is independent of EDTA concentration and depends on only that of hydrogen ions. The half-life time of $\mathrm{Zn}(\mathrm{II})\left(\mathrm{TPPS}_{4}\right)$ is $8.7 \times 10^{10} \mathrm{~s}\left(=10^{6}\right.$ d) at $\mathrm{pH} 6.0$; this value was calculated from the aciddissociation rate constant of $\mathrm{Zn}(\mathrm{II})\left(\mathrm{TPPS}_{4}\right)$. $\mathrm{Zn}(\mathrm{II})-$ (TPPS 4 ) dissociates $4 \times 10^{11}$ times as slow as $\mathrm{Pb}(\mathrm{II})$ $\left(\mathrm{TPPS}_{4}\right)$ at $\mathrm{pH} 6.0$ and at $C_{\mathrm{EDTA}}=10^{-2} \mathrm{~mol} \mathrm{dm}^{-3}$. The large kinetic difference is comparable to the previous kinetic results concerning $\mathrm{Cd}(\mathrm{II})\left(\mathrm{TPPS}_{4}\right)$ and $\mathrm{Zn}(\mathrm{II})-$ $\left(\mathrm{TPPS}_{4}\right){ }^{10}$ The kinetic behavior also supports the qualitative observation of $\mathrm{Cd}(\mathrm{II})\left(\mathrm{TPPS}_{4}\right)$ and $\mathrm{Zn}(\mathrm{II})-$ (TPPS ${ }_{4}$ ) reported by Ishii and Tsuchiai. ${ }^{12}$ We will report the detail reaction mechanism for the ligand-substitution reaction of the metalloporphyrins with EDTA elsewhere.

The large difference between $\mathrm{Pb}(\mathrm{II})-$ and $\mathrm{Zn}(\mathrm{II})-$ $\left(\mathrm{TPPS}_{4}\right)$ in their equilibrium and kinetic behavior allows the determination of zinc(II) in the presence of a large amount of lead(II). Figure 2 shows absorption spectra observed after the ligand-substitution reaction

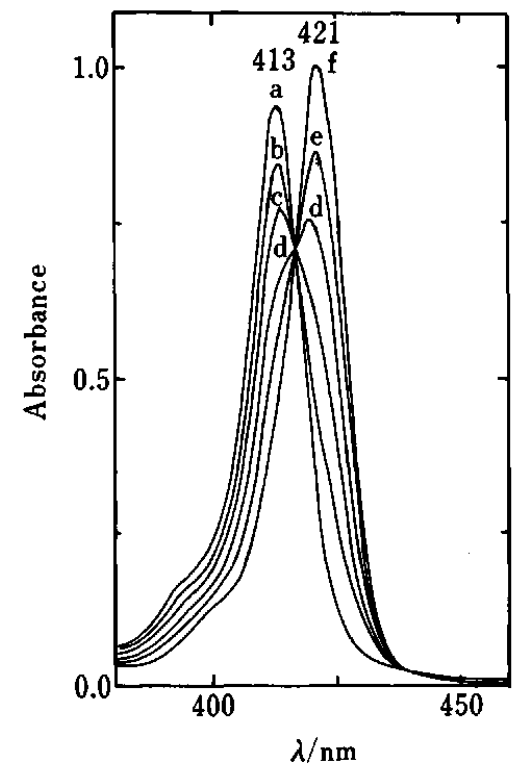

Fig. 2 Absorption spectra observed after the addition of EDTA to solutions of $\mathrm{Zn}(\mathrm{II})$ - and $\mathrm{Pb}(\mathrm{II})\left(\mathrm{TPPS}_{4}\right)$ mixture. $C_{\text {H2TPPS4}}, 2.0 \times 10^{-6} \mathrm{~mol} \mathrm{dm}^{3} ; C_{\text {EDTA }}, 1.00 \times 10^{-3} ; \mathrm{pH} 6.0$. Concentrations of $\mathrm{Zn}(\mathrm{II}) / 10^{-7} \mathrm{~mol} \mathrm{dm}^{-3}: 0$ (a); 2.97 (b); 5.91 (c); 8.87 (d); $11.8(\mathrm{e}) ; 14.7$ (f). with EDTA at various concentrations of zinc(II) $\left(1.0 \times 10^{-7}-1.5 \times 10^{-6} \mathrm{~mol} \mathrm{dm}^{-3}: 6-100 \mathrm{ppb} \mathrm{Zn}\right)$ in the presence of lead(II) $\left(1 \times 10^{-3} \mathrm{~mol} \mathrm{dm}^{-3}\right)$. The absorbance change at $421 \mathrm{~nm}$ is linearly correlated to the concentration of zinc(II) against the reagent blank. The molar absorptivity is $4.66 \times 10^{5} \mathrm{~mol}^{-1} \mathrm{dm}^{3} \mathrm{~cm}^{-1}$.

\section{Rate of formation of $\mathrm{Zn}(\mathrm{II})\left(\mathrm{TPPS}_{4}\right)$}

The rate of formation of matalloporphyrin is very slow except for mercury(II), cadmium(II) and lead(II). ${ }^{6}$ The reaction, however, is accelerated $10^{3}$ to $10^{4}$ times in the presence of mercury(II), cadmium(II) or lead(II). Their metalloporphyrins make it easy for the medium size of metal ions to attack the porphyrin plane from the back.6,15 Figure 3 shows the catalytic effect of lead(II) on the formation of $\mathrm{Zn}(\mathrm{II})\left(\mathrm{TPPS}_{4}\right)$. Pyridine, imidazole and amino acids also catalyze the formation of $\mathrm{Zn}(\mathrm{II})\left(\mathrm{TPPS}_{4}\right)$ by about 10 to 100 times, as reported by Ishii and Tsuchiai ${ }^{12}$, and Kawamura et al. ${ }^{16}$ The catalysts (L) form the molecular complexes as a reaction intermediate of $\mathrm{ZnL} \cdot \mathrm{H}_{2} \mathrm{TPPS}_{4}$ through a hydrophobic interaction between the catalysts $(\mathrm{L})$ and the porphyrin plane. ${ }^{17} \mathrm{Zn}(\mathrm{II})\left(\mathrm{TPPS}_{4}\right)$ is completely formed within $20 \mathrm{~min}$ in the presence of lead(II) $\left(10^{-3}\right.$ mol dm$\left.{ }^{-3}\right)$ and imidazole $\left(5 \times 10^{-2} \mathrm{~mol} \mathrm{dm}^{-3}\right)$ (Fig. 3).

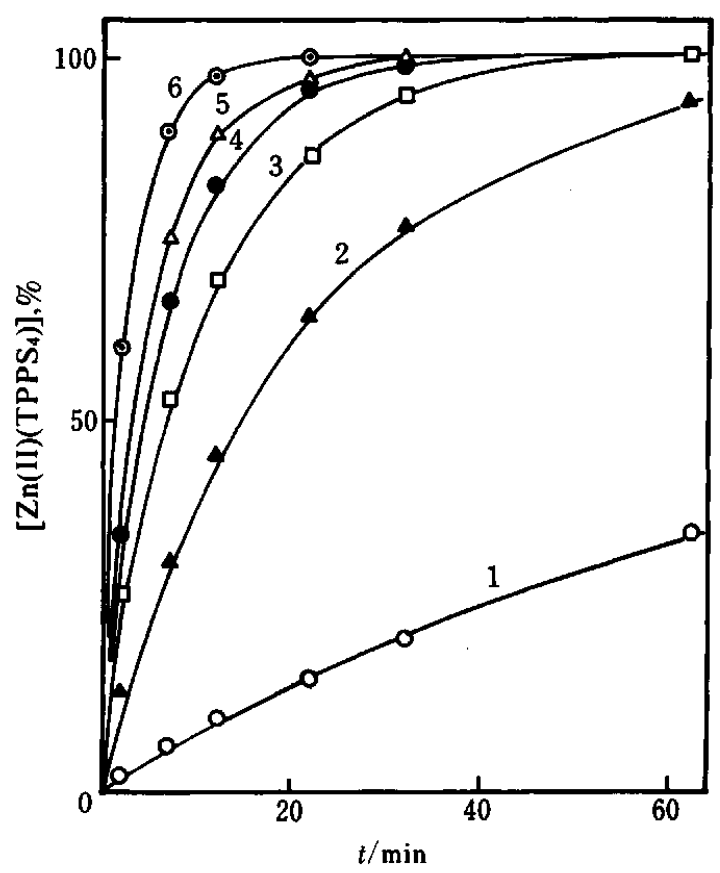

Fig. 3 Rate of the formation of $\mathrm{Zn}(\mathrm{II})\left(\mathrm{TPPS}_{4}\right)$ at $25^{\circ} \mathrm{C}, \mathrm{pH}$ $6.0, C_{\mathrm{H} 2 \mathrm{TPPS} 4}=1.00 \times 10^{-6}$ and $C_{\mathrm{Zn}}=3.87 \times 10^{-6}$ in the absence $(1, O)$ and presence $(2, \Delta-6, \odot)$ of lead(II) and catalysts $(\mathrm{L})$. $C_{\mathrm{Pb}}=9.80 \times 10^{-4}$ for (2) to (6). Catalysts and their concentrations are pyridine $=9.81 \times 10^{-3}(3, \square)$, imidazole $=9.79 \times 10^{-3}$ $(4,0)$, pyridine $=9.81 \times 10^{-3}$ and imidazole $=9.79 \times 10^{-3}(5, \Delta)$, imidazole $=4.89 \times 10^{-2}(6)$. Unit of concentration is $\mathrm{mol} \mathrm{dm}^{-3}$ for all solutions. 
Table 1 Effect of foreign ions on the determination of zinc(II) in the presence of lead(II)

\begin{tabular}{lcr}
\hline lon & Concentration $/ \mathrm{mol} \mathrm{dm}^{-3}$ & Recovery, \% \\
\hline $\mathrm{Ca}^{2+}$ & $1.00 \times 10^{-3}$ & 106 \\
$\mathrm{Mg}^{2+}$ & $1.00 \times 10^{-3}$ & 97 \\
$\mathrm{Sr}^{2+}$ & $1.00 \times 10^{-4}$ & 100 \\
$\mathrm{Ba}^{2+}$ & $1.00 \times 10^{-4}$ & 96 \\
$\mathrm{Mn}^{2+}$ & $9.98 \times 10^{-6}$ & 87 \\
$\mathrm{Fe}^{3+}$ & $9.90 \times 10^{-6}$ & 106 \\
$\mathrm{Al}^{3+}$ & $1.00 \times 10^{-5}$ & 100 \\
$\mathrm{Co}^{2+}$ & $1.00 \times 10^{-5}$ & 78 \\
$\mathrm{Ni}^{2+}$ & $1.00 \times 10^{-5}$ & 102 \\
$\mathrm{Cu}^{2+}$ & $1.01 \times 10^{-5}$ & 56 \\
$\mathrm{Hg}^{2+}$ & $1.01 \times 10^{-5}$ & 104 \\
$\mathrm{Cd}^{2+}$ & $1.00 \times 10^{-3}$ & 105 \\
$\mathrm{Cl}^{-}$ & $1.00 \times 10^{-4}$ & 102 \\
$\mathrm{Br}^{-}$ & $9.96 \times 10^{-4}$ & 96 \\
$\mathrm{I}^{-}$ & $1.00 \times 10^{-3}$ & 102 \\
$\mathrm{SCN}^{-}$ & $1.00 \times 10^{-4}$ & 101 \\
$\mathrm{SO}_{4}^{2-}$ & $1.00 \times 10^{-5}$ & 100 \\
$\mathrm{~S}_{2} \mathrm{O}_{3}^{2-}$ & $1.00 \times 10^{-4}$ & 99 \\
$\mathrm{SiO}_{3}^{2-}$ & $9.95 \times 10^{-5}$ & 102 \\
$\mathrm{H}_{2} \mathrm{PO}_{4}^{-}$ & $1.00 \times 10^{-5}$ & 97 \\
\hline
\end{tabular}

Zinc(II), $8.87 \times 10^{-7} \mathrm{~mol} \mathrm{dm}^{-3}$; lead(II), $1 \times 10^{-3} \mathrm{~mol} \mathrm{dm}^{-3}$; $25^{\circ} \mathrm{C} ; \mathrm{pH} 6.0 ; C_{\mathrm{H} 2 \mathrm{TPPS}}, 2.00 \times 10^{-6} \mathrm{~mol} \mathrm{dm}^{-3} ; C_{\text {imidazole }}, 0.05$ $\mathrm{mol} \mathrm{dm} \mathrm{m}^{-3}$.

\section{Effect of foreign ions}

Table 1 shows the effect of the various cations and anions usually encountered in the determination of zinc(II). Most substances do not interfere with the determination of $8.87 \times 10^{-7} \mathrm{~mol} \mathrm{dm}^{-3}$ zinc(II), but copper(II), cobalt(II) and manganese(II) do. Such interference was removed by using a ligand-buffer solution consisting of aminopolycarboxylates ( $Y=$ EDTA, HEDTA and EGTA) and lead(II).

\section{Optimum composition of ligand-buffer solution}

Nakagawa and Tanaka have proposed the use of a ligand-buffer solution for the porlarographic determination of zinc(II) in the presence of cadmium. ${ }^{18} \mathrm{We}$ determined the optimum composition of ligand-buffer solution to mask copper(II), cobalt(II) and manganese(II) for the determination of zinc(II) in a sample containing a large amount of lead(II), as follows.

In order to mask $\mathrm{N}(\mathrm{Cu}(\mathrm{II}), \mathrm{Co}(\mathrm{II}), \mathrm{Mn}(\mathrm{II}))$ as completely as possible, most of $\mathrm{N}$ should be the form of NY:

$$
[\mathrm{NY}] /[\mathrm{N}]=K_{\mathrm{NY}}[\mathrm{Y}] \gg 1,
$$

and zinc(II) should be free ions:

$$
[\mathrm{ZnY}] /\left[\mathrm{Zn}^{2+}\right]=K_{\mathrm{ZnY}}[\mathrm{Y}] \ll 1
$$

where $K_{\mathrm{NY}}$ and $K_{\mathrm{ZnY}}$ refer the formation constants of metal ion $\mathrm{N}$ and zinc(II) with $\mathrm{Y}$, respectively. Lead(II) to be added as a component of the ligand buffer for masking the metal $\mathrm{N}$ should satisfy the condition:
Table 2 Effect of components of ligand buffer on the determination of zinc(II) by the present method

\begin{tabular}{cccc}
\hline $\mathrm{Y}$ & $\begin{array}{c}C_{\mathrm{Y}} / \\
\mathrm{mol} \mathrm{dm}\end{array}$ & $\begin{array}{c}C_{\mathrm{Pb}} \\
\mathrm{mol} \mathrm{dm}\end{array}$ & $\begin{array}{c}\text { Recovery of } \\
\mathrm{Zn}, \%\end{array}$ \\
\hline EDTA & $1.00 \times 10^{-3}$ & $2.00 \times 10^{-3}$ & 103 \\
& $1.00 \times 10^{-3}$ & $3.00 \times 10^{-3}$ & 104 \\
& $1.00 \times 10^{-3}$ & $4.00 \times 10^{-3}$ & 102 \\
& $5.00 \times 10^{-4}$ & $1.00 \times 10^{-3}$ & 101 \\
HEDTA & $5.00 \times 10^{-4}$ & $2.00 \times 10^{-3}$ & 103 \\
& $1.00 \times 10^{-3}$ & $2.00 \times 10^{-3}$ & 100 \\
& $1.00 \times 10^{-3}$ & $3.00 \times 10^{-3}$ & 103 \\
& $1.00 \times 10^{-3}$ & $4.00 \times 10^{-3}$ & 104 \\
& $5.03 \times 10^{-4}$ & $1.00 \times 10^{-4}$ & 98 \\
EGTA & $5.03 \times 10^{-4}$ & $2.00 \times 10^{-4}$ & 102 \\
& $1.01 \times 10^{-3}$ & $2.00 \times 10^{-3}$ & 96 \\
& $1.01 \times 10^{-3}$ & $3.00 \times 10^{-3}$ & 104 \\
& $1.01 \times 10^{-3}$ & $4.00 \times 10^{-3}$ & 102 \\
& $1.01 \times 10^{-4}$ & $2.00 \times 10^{-3}$ & 100 \\
& $2.02 \times 10^{-4}$ & $2.00 \times 10^{-3}$ & 101 \\
& $3.03 \times 10^{-4}$ & $2.00 \times 10^{-3}$ & 99 \\
\hline
\end{tabular}

$C_{\mathrm{Zn}}, 8.87 \times 10^{-7} \mathrm{~mol} \mathrm{dm}^{-3} ; C_{\mathrm{H} 2 \mathrm{TPPS}}, 2.00 \times 10^{-6} \mathrm{~mol} \mathrm{dm}^{-3} ; \mathrm{pH}$ 6.0.

$K_{\mathrm{NY}}>K_{\mathrm{PbY}}>K_{\mathrm{ZnY}}$. The concentration of free $\mathrm{Y}$ in the ligand buffer is calculated from the following equation:

$$
[\mathrm{Y}]=C_{\mathrm{Y}}\left(C_{\mathrm{Pb}}-C_{\mathrm{Y}}\right)^{-1} K_{\mathrm{PbY}}^{-1}
$$

where $C_{\mathrm{Y}}$ and $C_{\mathrm{Pb}}$ denote the total concentrations of $\mathrm{Y}$ and lead(II), respectively.

EDTA, HEDTA and EGTA satisfying the condition of $K_{\mathrm{ZnY}}<K_{\mathrm{PbY}}<K_{\mathrm{NY}}$ were used to mask copper(II), cobalt(II) and manganese(II) as the components of the ligand buffer. Cobalt(II) and manganese(II) complexes were oxidized to the corresponding trivalent metal complexes by hydrogen peroxide. The formation constants (logarithmic values) of zinc, lead and copper with EDTA, HEDTA and EGTA are 16.4, 17.9 and 18.7 for EDTA, 14.6, 15.5 and 17.5 for HEDTA, and 12.6, 14.5 and 17.6 for EGTA, respectively. ${ }^{2}$ Table 2 summarizes the recovery of zinc(II) in the ligand-buffer solution containing aminopolycarboxylates and lead(II) in different portions. When $C_{\mathrm{Pb}} / C_{\mathrm{Y}}$ is $>2$, the recovery of zinc(II) is quantitative for all three aminopolycarboxylates. Thus the following conditions were used to remove the interference of copper, cobalt and manganese: $C_{\mathrm{Pb}}=2 \times 10^{-3} \mathrm{~mol} \mathrm{dm}^{-3}$ and $C_{\mathrm{Y}}=1 \times 10^{-3} \mathrm{~mol} \mathrm{dm}^{-3}$ for the ligand buffers of Pb-EDTA and Pb-HEDTA components, and $C_{\mathrm{Pb}}=2 \times 10^{-3} \mathrm{~mol} \mathrm{dm}^{-3}$ and $C_{Y}=2 \times 10^{-4}$ $\mathrm{mol} \mathrm{dm}{ }^{-3}$, for that of $\mathrm{Pb}-\mathrm{EGTA}$ component, respectively. The results are listed in Table 3 . It was easy to mask cobalt(II) by oxidation to cobalt(III) complexes, but manganese was not sufficiently masked by the present method. This is because manganese(III)aminopolycarboxylate complex would undergo a slow decomposition. ${ }^{19}$ Lead chemicals contain copper as a major impurity, at an extent of $\leqq 0.001 \%$. Thus EGTA 
Table 3 Masking of copper(II), cobalt(II) and manganese(II) by the ligand buffer $\left(C_{\mathrm{Zn}}=8.87 \times 10^{-7} \mathrm{~mol} \mathrm{dm}^{-3} ; C_{\mathrm{H} 2 \mathrm{TPPS} 4}=\right.$ $2.0 \times 10^{-6} \mathrm{~mol} \mathrm{dm}^{-3}$ )

\begin{tabular}{ccccc}
\hline \multirow{2}{*}{ Ion } & $\begin{array}{c}\text { Concentration/ } \\
\text { mol dm }^{-3}\end{array}$ & \multicolumn{3}{c}{ Recovery of Zn, \% } \\
EDTA $^{\mathrm{a}}$ & HEDTA $^{\mathrm{a}}$ & EGTA $^{\mathrm{a}}$ \\
\hline $\mathrm{Cu}^{2+}$ & $2.01 \times 10^{-6}$ & 86 & 96 & 96 \\
& $5.05 \times 10^{-6}$ & 69 & 85 & 97 \\
& $1.01 \times 10^{-5}$ & 50 & 69 & 96 \\
& $5.05 \times 10^{-5}$ & 11 & 27 & 72 \\
$\mathrm{Co}^{2+}$ & $2.00 \times 10^{-6}$ & & & 96 \\
& $5.00 \times 10^{-6}$ & 99 & 102 & 94 \\
& $1.00 \times 10^{-5}$ & 98 & 100 & 91 \\
& $5.00 \times 10^{-5}$ & 94 & 96 & 60 \\
$\mathrm{Mn}^{2+}$ & $1.97 \times 10^{-6}$ & & & 90 \\
& $5.02 \times 10^{-6}$ & 79 & 90 & 79 \\
& $9.98 \times 10^{-6}$ & 72 & 75 & 71 \\
\hline
\end{tabular}

a. Components of the ligand buffers are $C_{\mathrm{Pb}}=2.00 \times 10^{-3}$ $\mathrm{mol} \mathrm{dm} \mathrm{d}^{-3}$ and $C_{\mathrm{Y}}=1.0 \times 10^{-3} \mathrm{~mol} \mathrm{dm}^{-3}$ for EDTA and HEDTA, and are $C_{\mathrm{Pb}}=2.00 \times 10^{-3} \mathrm{~mol} \mathrm{dm}^{-3}$ and $C_{\mathrm{Y}}=2.02 \times$ $10^{-4} \mathrm{~mol} \mathrm{dm}^{-3}$ for EGTA.

was chosen for the selective masking of copper in the presence of lead(II), because the difference of the formation constants between $\mathrm{Pb}(\mathrm{II})$ (EGTA) and $\mathrm{Cu}(\mathrm{II})$ (EGTA) complexes is larger than that of the corresponding EDTA and HEDTA complexes. Experimental results (Table 3) also reveal that copper was more masked by EGTA than EDTA or HEDTA.

\section{Determination of zinc in lead chemicals and tap and waste waters}

The present method was applied to the determination of zinc(II) in lead(II) nitrate, lead(II) acetate and lead metal, and in tap and waste waters. Lead chemicals were analyzed as follows. A sample of lead chemicals $(10-200 \mathrm{mg} \mathrm{Pb})$ was taken into a brown $50 \mathrm{~cm}^{3}$ volumetric flask; then $5 \mathrm{~cm}^{3}$ of acetate buffer $(\mathrm{pH} \mathrm{6}$; $5 \times 10^{-1} \mathrm{~mol} \mathrm{dm}^{-3}$ ), a half equivalent of EGTA to lead(II), $2.5 \mathrm{~cm}^{3}$ of imidazole $\left(10^{-1} \mathrm{~mol} \mathrm{dm}^{-3}\right)$, and $1 \mathrm{~cm}^{3}$ of $\mathrm{H}_{2}$ TPPS $_{4}\left(1.0 \times 10^{-4} \mathrm{~mol} \mathrm{dm}^{-3}\right)$ were added. The solution was allowed to stand for $30 \mathrm{~min}$ to complete the formation of $\mathrm{Zn}\left(\mathrm{TPPS}_{4}\right)$. A $2 \mathrm{~cm}^{3}$ portion of EDTA $\left(2.5 \times 10^{-1} \mathrm{~mol} \mathrm{dm}^{-3}\right)$ was added to the solution to replace the formed $\mathrm{Pb}(\mathrm{II})\left(\mathrm{TPPS}_{4}\right)$ with EDTA. Concentration of zinc was determined from measurement of the absorbance at $421 \mathrm{~nm}$. For the determination of zinc in waters, $2 \mathrm{~cm}^{3}$ of lead(II) nitrate $\left(5 \times 10^{-2} \mathrm{~mol}\right.$ $\left.\mathrm{dm}^{-3}\right)$ and $2 \mathrm{~cm}^{3}$ of EGTA $\left(5 \times 10^{-3} \mathrm{~mol} \mathrm{dm}^{-3}\right)$ were added to a sample solution before adding imidazole. The other procedure was the same as for the analysis of zinc in lead chemicals. The results for the determination of zinc in lead chemicals and waters are collected in Table 4. A few ppm level of zinc was found in these samples. Concentrations of zinc in lead(II) nitrates were also checked by an atomic absorption spectrophotometric method: zinc concentrations found in lead nitrates purchased from A Co. Ltd., B Co. Ltd. and C
Table 4 Determination of zinc(II) in lead chemicals and waters by the present method

\begin{tabular}{|c|c|c|c|}
\hline \multirow{2}{*}{ Sample } & \multirow{2}{*}{$\begin{array}{l}\text { Taken }{ }^{\mathrm{a}} / \\
\text { g or } \mathrm{cm}^{3}\end{array}$} & \multicolumn{2}{|c|}{ Zinc(II) found } \\
\hline & & $\mu g$ & ppm \\
\hline \multicolumn{4}{|c|}{ Lead nitrate (G.R) } \\
\hline \multirow[t]{2}{*}{ A. Co. Ltd. } & 0.166 & 0.569 & 3.4 \\
\hline & 0.332 & 1.080 & 3.3 \\
\hline \multirow[t]{2}{*}{ B. Co. Ltd. } & 0.166 & 0.092 & 0.6 \\
\hline & 0.332 & 0.245 & 0.7 \\
\hline \multicolumn{4}{|c|}{ Lead nitrate (E.R) } \\
\hline \multirow[t]{2}{*}{ C. Co. Ltd. } & 0.166 & 0.268 & 1.6 \\
\hline & 0.332 & 0.507 & 1.5 \\
\hline \multirow[t]{2}{*}{ B. Co. Ltd. } & 0.166 & 0.575 & 3.5 \\
\hline & 0.332 & 1.080 & 3.3 \\
\hline \multicolumn{4}{|c|}{ Lead acetate (G.R) } \\
\hline \multirow[t]{2}{*}{ B. Co. Ltd. } & 0.190 & 0.062 & 0.3 \\
\hline & 0.380 & 0.170 & 0.4 \\
\hline \multicolumn{4}{|c|}{ Lead metal (G.R) ${ }^{b}$} \\
\hline \multirow[t]{2}{*}{ A. Co. Ltd } & 0.104 & 0.434 & 4.2 \\
\hline & 0.208 & 0.905 & 4.4 \\
\hline \multirow[t]{2}{*}{ Tap water } & 1.0 & 0.791 & 0.79 \\
\hline & 2.0 & 1.590 & 0.80 \\
\hline \multirow[t]{2}{*}{ Waste water } & 10.0 & 1.020 & 0.10 \\
\hline & 20.0 & 2.000 & 0.10 \\
\hline
\end{tabular}

a. Units are $\mathrm{g}$ for lead chemicals and $\mathrm{cm}^{3}$ for waters, respectively.

b. Lead metal of $2.08 \mathrm{~g}$ was dissolved by nitric acid and dried, and followed by dissolving in a $100 \mathrm{~cm}^{3}$ volumetric flask. A 5 or $10 \mathrm{~cm}^{3}$ aliquot of the solution was analyzed.

Co. Ltd. were $3.3 \mathrm{ppm}, 0.6 \mathrm{ppm}$ and $1.6 \mathrm{ppm}$, respectively. The values are sufficiently in agreement with those obtained by the present method (see Table 4).

The present method is based on a kinetic difference of $4 \times 10^{11}$ times and an equilibrium difference of $10^{9}$ times in the reactivity of $\mathrm{Pb}(\mathrm{II})-$ and $\mathrm{Zn}(\mathrm{II})\left(\mathrm{TPPS}_{4}\right)$. The proposed method is so selective and sensitive that $10^{-7} \mathrm{~mol} \mathrm{dm}^{-3}$ zinc(II) can be determined in the presence of $10^{5}$ times excess of lead in water. Molar absorptivity of $\mathrm{Zn}\left(\mathrm{TPPS}_{4}\right)$ is $4.66 \times 10^{5} \mathrm{~mol}^{-1} \mathrm{dm}^{3} \mathrm{~cm}^{-1}$. The calibration curve is linear in the range of $0-100 \mathrm{ng} \mathrm{Zn} / \mathrm{cm}^{3}$. Determination limits were $1 \mathrm{ng} \mathrm{Zn} / \mathrm{cm}^{3}$ in waters and $20 \mathrm{ng} \mathrm{Zn/g}$ in lead chemicals. Recoveries were 96.5 $104.6 \%$.

The authors wish to express their thanks Dr. Motoharu Tanaka (an Honorary Professor of Nagoya University) for his helpful comments. We also gratefully acknowledge the financial support of this study by a Grant-in-Aid for Scientific Research (No. 01470030) from the Ministry of Education, Science and Culture.

\section{References}

1. E. B. Sandell, "Colorimetric Determination of Traces of Metals", 3rd ed., pp. 941 -965, Interscience, New York, 1965. 
2. A. E. Martell and S. Smith, "Critical Stability Constants", Vols. 1 - 3, Plenum, New York, 1974.

3. S. E. Haye and P. Hambright, Inorg. Chem., 23, 4778 (1984).

4. Private communication, T. Yotsuyanagi (Tohoku University), 1985.

5. M. Tabata and M. Tanaka, Anal. Lett., 13, 427 (1980).

6. M. Tabata and M. Tanaka, J. Chem. Soc. Dalton Trans., $1983,1955$.

7. M. Tabata and M. Tanaka, J. Chem. Soc. Chem. Commun., 1985, 42.

8. P. F. Rodesiler, E. A. H. Griffith, N. G., Charles, L. Lebioda and E. L. Amma, Inorg. Chem., 24, 4595 (1985).

9. K. M. Barkigia, J. Fajer, A. D. Adler and G. J. B. Williams, Inorg. Chem., 19, 2057 (1980).

10. M. Tabata, K. Oshita and M. Tanaka, Mikrochim. Acta [Wien], 1985 I, 397.
11. J. Turay and P. Hambright, Inorg. Chem., 19, 564 (1980).

12. H. Ishii and H. Tsuchiai, Anal. Sci., 3, 229 (1987).

13. W. R. Scheidt, M. E., Kastner and K. Hatano, Inorg. Chem., 17, 706 (1978).

14. C. K. Schauer, O. P. Anderson, S. S. Eaton and G. Eaton, Inorg. Chem., 24, 4082 (1985).

15. M. Tabata, Analyst [London], 112, 141 (1987).

16. K. Kawamura, S. Igarashi and T. Yotsuyanagi, Anal. Sci., 4, 175 (1988).

17. M.Tabata and M. Tanaka, Inorg. Chem., 27, 203 (1988).

18. G. Nakagawa and M. Tanaka, Talanta, 19, 559 (1972).

19. F. A. Cotton and G. Wilkinson, "Advanced Inorganic Chemistry", 4th ed., p. 741, John Wiley and Sons, New York, 1980.

(Received July 8, 1989)

(Accepted September 4, 1989) 